Христенко О. А., кандидат економічних наук, доцент кафедри економіки підприємств, Миколаївський національний аграрний університет, м. Миколаїв, Україна

ORCID ID: 0000-0003-0431-5328

e-mail: olhakhrystenko@gmail.com

Тимофєєва Т. С., здобувач вищої освіти факультету менеджменту, Миколаївський національний аграрний університет, м. Миколаїв, Україна

e-mail: timofeeva_ts@outlook.com

\title{
Соціальна складова забезпечення сталого розвитку
}

\begin{abstract}
Анотація. Досліджено соціальну складову сталого розвитку в Україні, встановлено проблеми, які пов'язані з якістю життя населення. Методичну основу дослідження склали загальнонаукові методи, зокрема: метод порівняння, аналізу і синтезу, статистичний та соціологічний метод. Використовувалися також комп'ютерні методи обробки інформації й візуалізації результатів дослідження. Проаналізовано глобальну сутність концепції сталого розвитку. Встановлено, що якість життя населення є однією з головних характеристик рівня суспільного розвитку країни. Визначено основні показники, що характеризують якість життя та проведено аналіз їхнього рівня для України. Визначено пріоритетні напрямки покращення якості життя країни. Поглиблено теоретичний базис дослідження сталого розвитку в Украӥні; виявлено суспільно-важливі чинники, що впливають на якість життя населення та встановлено пріоритетні напрямки їх зростання. Особливого значення надається дослідженню кроків до запровадження комплексного сталого розвитку. Результати даної теми дослідження можуть бути використані на різних семінарських зібраннях, які мають інтерес у дослідження сталого розвитку суспільства, зокрема покращенні якості життя населення. Можливе також їх використання у подальших дослідженнях для розв'язання відповідних проблем.
\end{abstract}

Ключові слова: сталий розвиток; якість життя; освіта; здоров'я; зайнятість та безробіття; стратегія розвитку; якість середовища.

Khrystenko 0., Ph.D. (Economics), Associate Professor of the Department of Enterprise Economics, Mykolayiv National Agrarian University, Mykolayiv, Ukraine

Timofeeva T., Higher Education Learner of Management Faculty, Mykolayiv National Agrarian University, Mykolayiv, Ukraine

\section{Social Component Providing of Sustainable Development}

The article aims to investigate the social component of providing sustainable development in Ukraine, identify issues related to the quality of life of the population.

Research methodology. The methodological basis for the study was general scientific methods, in particular: the method of comparison, analysis, and synthesis, statistical and sociological method. Computer methods of information processing and visualization of research results using the Microsoft Office program were also used.

Research results. It is established that the quality of life of the population is one of the main characteristics of the level of social development of the country. The basic indicators characterizing the quality of life are determined and the analysis of their level for Ukraine is carried out. The priority directions of improvement of the quality of life of the country are determined.

Scientific novelty of research results. An in-depth theoretical basis for the study of sustainable development in Ukraine; socially important factors influencing the quality of life of the population were identified and priority directions of their growth were established.

The practical significance of the research results. The results of this topic of research can be used at various seminar meetings that are of interest to the study of sustainable development of society, in particular, improving the quality of life of the population. It is also possible to use them in further research to solve the problems. It is proved that the quality of life of the population is an integral concept, which provides for the analysis of all spheres of life of society. Improving the quality of life is a criterion and a prerequisite for human development.

Keywords: sustainable development; quality of life; education; health; employment and unemployment; strategy of development; quality of environment.

JEL Classification: A13.

Постановка проблеми. Наприкінці XX століття в багатьох сферах світового розвитку поглибилися кризові явища. Така ситуація поставила людство перед необхідністю формування нового світогляду, обґрунтування нових цінностей, морально-етичних критеріїв та корекції спільних цілей і пріоритетів. Після

Стаття надійшла до редакції: 18.12.2019

Received: 18 December 2019 
завершення «холодної війни», коли виникли сприятливі умови кооперування, інтеграції, розширення міжнародної співпраці для вирішення актуальних проблем, що постали перед світовою спільнотою, як ніколи потрібна ідея, мета, котра $б$ об'єднувала народи й держави. Найбільш прийнятною метою в найближчому майбутньому, вважають фахівці, може бути сталий розвиток людства.

Аналіз останніх досліджень і публікацій. Теоретичні основи сталого розвитку суспільства у своїх працях досліджували як вітчизняні, так і зарубіжні науковці, а саме: 3. Герасимчук, Н.Гребенюк, О.Грянник, Б. Данилишин, С. Дорогунцов, О. Котикова, Л. Мельник, В. Міщенко, В. Прадун, В. Тихонов, А. Трегобчук, Л. Шостак, В. Шевчук, М. Шапочка та інші.

Формулювання цілей дослідження. Метою статті $\epsilon$ дослідження соціальної складової сталого розвитку в Україні, встановлення проблем пов'язаних з якістю життя населення.

Виклад основного матеріалу. Сталий розвиток відноситься до моделі людського розвитку, в межах якої використання ресурсів спрямоване на задоволення людських потреб 3 одночасним забезпеченням сталості природних систем та навколишнього середовища, щоб ці потреби могли бути задоволені не тільки для нинішнього, а й для майбутніх поколінь [1].

У 50-60-х рр. XX ст. розвиток пов'язували лише 3 економічним прогресом та зростанням економічної ефективності. На початку 70-х рр. у зв'язку 3 несправедливим розподілом прибутків та зі зростанням кількості бідних у країнах, що розвиваються, питання соціальної справедливості були визнані такими ж важливими, як і питання зростання економічної ефективності. Проте дедалі більше споживання природних ресурсів призвело до деградації довкілля й негативно вплинуло на здоров'я людей [3].

Світова спільнота визнала, що збалансований розвиток «повинен стати пріоритетним питанням порядку денного міжнародного співробітництва». Загальновизнаним $€$ розуміння збалансованого розвитку як гармонійного поєднання економічних, соціальних та екологічних складових розвитку [2]. Лише досягнення збалансованості між ними забезпечить можливість перейти до такого суспільного розвитку, який не виснажуватиме природні та людські ресурси, а тому матиме можливість тривати досить довго.

Стратегія сталого розвитку суспільства включає три основні складові (рис. 1).

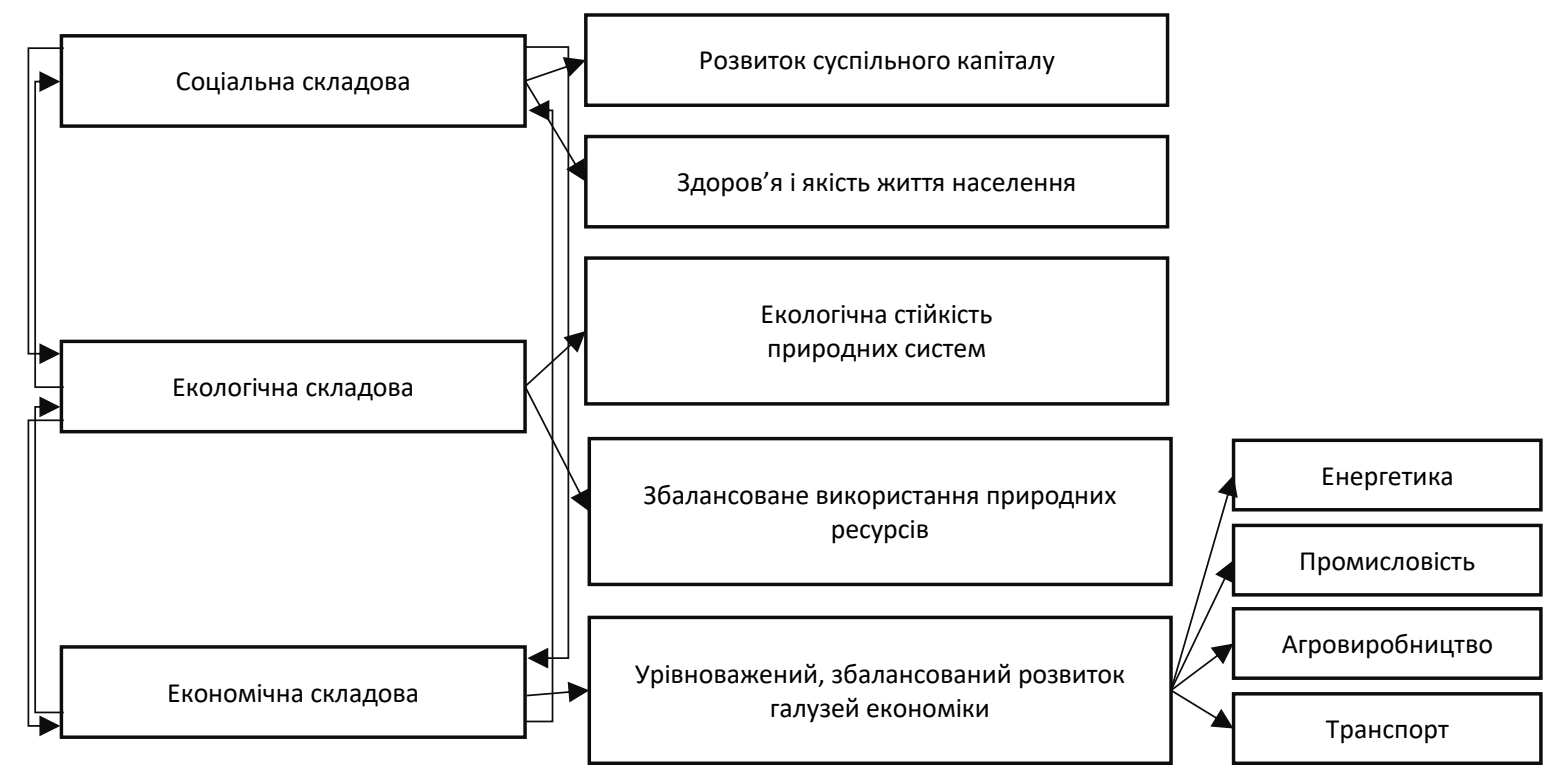

Рисунок 1 - Складові соціального розвитку

Джерело: побудовано авторами на основі [2]

Мета сталого розвитку у національному вимірі полягає у формуванні балансу соціальних, екологічних та економічних складових розвитку задля досягнення економічного зростання і підвищення якості життя людей, зменшення соціальної, гендерної, територіальної нерівностей, оптимальне використання природних ресурсів, подолання кліматичних та екологічних проблем [7].

Міжнародною спільнотою якість життя визнана однією з головних характеристик рівня суспільного розвитку країни. Поступово відходять у минуле орієнтири переважно на економічні результати та впровадження досягнень науково-технічного прогресу 
без урахування пріоритетного розвитку людського чинника.

Підвищення якості життя людей у поєднанні зі створенням належних умов для реалізації інноваційної моделі економічного зростання, досягнення і перетворення високих стандартів якості життя у потужний чинник глобальної конкурентоспроможності України $€$ стратегічним управлінським завданням. Визначення основних компонентів та чинників впливу на якість життя населення, формування стратегії управління якістю життя дозволить забезпечити гармонізацію цілей економічного зростання, розвитку людини та збереження навколишнього середовища [5].

Поняття «якість життя» являє собою структурну цілісність, тому може бути представлене як єдність цілого і його частин:

- якість населення (демографічні характеристики, здоров'я, рівень освіти);

- якість середовища проживання (природноекологічні умови, економічний розвиток території, розвинутість соціальної інфраструктури, рівень особистої безпеки);

- якість діяльності (трудової, відпочинку, побутової, духовно-культурної і суспільно-політичної).

У другій половині XX століття динаміка показників демографії України характеризується швидким відновленням населення 3 подальшим зниженням темпів приросту й негативним приростом населення в 90-х роках. Так, упродовж першого повоєнного міжпереписного періоду (1959-1970 роки) чисельність населення зросла на 12,5 \%, протягом другого (19701979 роки) - на 5,4 \%, третього (1979-1989 роки) - лише на 3,7 \%. У період 1989-1993 років чисельність населення України зросла всього на 1,5 \%. Того ж 1993 року було зафіксовано найбільшу чисельність населення України - 52,2 млн осіб. Проте наприкінці 90-х років Україна почала втрачати населення, яке скоротилося на 7,2\% у 2001 році у порівнянні з 1993 роком. [6]. Проте сальдо міграції у період 2016-2018 рр. залишається позитивним і має чітку тенденцію до зростання (таблиця 1).

Таблиця 1 Основні демографічні показники України, осіб

\begin{tabular}{|c|c|c|c|c|c|}
\hline \multirow[t]{2}{*}{ Показник } & \multirow[t]{2}{*}{2016 p. } & \multirow[t]{2}{*}{2017 p. } & \multirow[t]{2}{*}{2018 p. } & \multicolumn{2}{|c|}{$\begin{array}{c}2018 \text { р. у порівнянні } 3 \\
2017 \text { р. }\end{array}$} \\
\hline & & & & Oci6 & $\%$ \\
\hline Народжених & 397037 & 363987 & 335874 & -28113 & 92,3 \\
\hline Померлих & 594796 & 574123 & 587665 & 13542 & 102,3 \\
\hline Природний рух & -197759 & -210136 & -251791 & -41655 & - \\
\hline Сальдо міграції & 10347 & 11997 & 18589 & 6592 & 154,9 \\
\hline
\end{tabular}

Джерело: розраховано авторами на основі [6]

В Україні спостерігається депопуляція населення, скорочення чисельності народжуваних (на 7,7\%) супроводжується збільшенням померлих (2,3\%). За даними Державної служби статистики смертність в Україні у 2017 році становила 14,4 \% (5-те місце у світі).

Віковий склад населення України, станом на 01.01.2018 року, має таку структуру:

- діти віком до 14 років - 15,76 \% (3 571358 чоловіків, 3366380 жінок);

- молодь віком 15-24 роки - 9,86 \% (2 226142 чоловіка, 2114853 жінки);

- дорослі віком 25-54 роки - 44,29 \% (9 579149 чоловіків, 9921387 жінок);

- особи перед похилого віку (55-64 роки) - 13,8 \% (2 605849 чоловіків, 3469246 жінок);

- особи похилого віку (65 років і старіші) - 16,3 \% (2 409049 чоловіків, 4770461 жінка) [6].

Співвідношення осіб, що в економічному плані залежать від інших, до осіб працездатного віку (15-64 роки) загалом становить 44, \% (станом на 2017 рік): частка дітей - 21,8 \%; частка осіб похилого віку - 23 \%, або 4,3 потенційно працездатного на 1 пенсіонера [6]. Загалом ці показники характеризують рівень необхідності державної допомоги в секторах освіти, охорони здоров'я та пенсійного забезпечення, відповідно.

Концепцію людського розвитку, яка наголошує на пріоритетності ролі людини, визначаючи, що людина мета економічного зростання, а не його ресурс, уведено в науковий обіг у 1990 році. Центральну тезу Програми Розвитку ООН визначено фразою: «Реальне багатство народів - люди». Метою людського розвитку $€$ створення середовища, яке надає людям можливість прожити довге, здорове і творче життя [5].

Суб'єктивне сприйняття рівня життя і тісно пов'язаної з ним якості життя формує певний тип поведінки індивідів в суспільстві, який, у свою чергу, впливає на зміну соціально-економічної політики держави, а, отже, і на формування можливостей та створення умов їх використання для задоволення потреб та інтересів людей. Фактори, що впливають на якість життя населення можна класифікувати за шістьома ознаками (таблиця 2). 
Електронне наукове фахове видання з економічних наук “Modern Economics», №18 (2019), 219 -223 https://modecon.mnau.edu.ua | ISSN 2521-6392

Таблиця 2 Класифікація факторів впливу на якість життя населення за різними ознаками

\begin{tabular}{|c|l|l|}
\hline № & \multicolumn{1}{|c|}{ Класифікаційна ознака } & \multicolumn{1}{c|}{ Перелік відповідних факторів } \\
\hline 1 & За змістом & $\begin{array}{l}\text { Економічні, соціально-демографічні, медичні, природно-географічні, екологічні, } \\
\text { релігійні, нормативно правові, інформаційні }\end{array}$ \\
\hline 2 & За оцінками якості життя & Об'єктивний аспект, суб'єктивний аспект \\
\hline 3 & За характером впливу & Позитивний, негативний \\
\hline 4 & За структурою якості життя & $\begin{array}{l}\text { Якість населення, якість середовища проживання, якість дозвілля та відпочинку, } \\
\text { якість функціонування }\end{array}$ \\
\hline 5 & За напрямком впливу & Зовнішні, внутрішні \\
\hline 6 & За часом дії & Постійні, тимчасові \\
\hline
\end{tabular}

Джерело: побудовано авторами на основі [2]

Як видно з таблиці, науковці виділяють лише ті фактори, що мають сприятливий або негативний вплив на формування якості життя населення. Наприклад, на зниження якості життя впливають: низький рівень оплати праці, ріст безробіття, тривала заборгованість виплати заробітної плати, пенсій, стипендій, соціальних виплат і тощо.

За даними Державної служби зайнятості України, протягом трьох останніх років рівень економічної активності населення України у віці 15-70 років, як і його абсолютна чисельність скорочується. Чисельність зайнятого населення у віці 15-70 років у I півріччі 2017 р. становила 16,1 млн осіб (у I півріччі 2016 р. - 16,2 млн осіб). Рівень зайнятості становив $56,0 \%$ у 2017 році (у I півріччі 2016 р. - 56,2\%). Зокрема, у міських поселеннях цей показник становив 56,9\%, а у сільській місцевості 54,0\%. Рівень зайнятості серед чоловіків був вище ніж серед жінок, відповідно 61,1\% та 51,4\%[6].

Важливими факторами, що впливають на якість життя населення $€$ податкова та інвестиційна політика держави (рис.2).

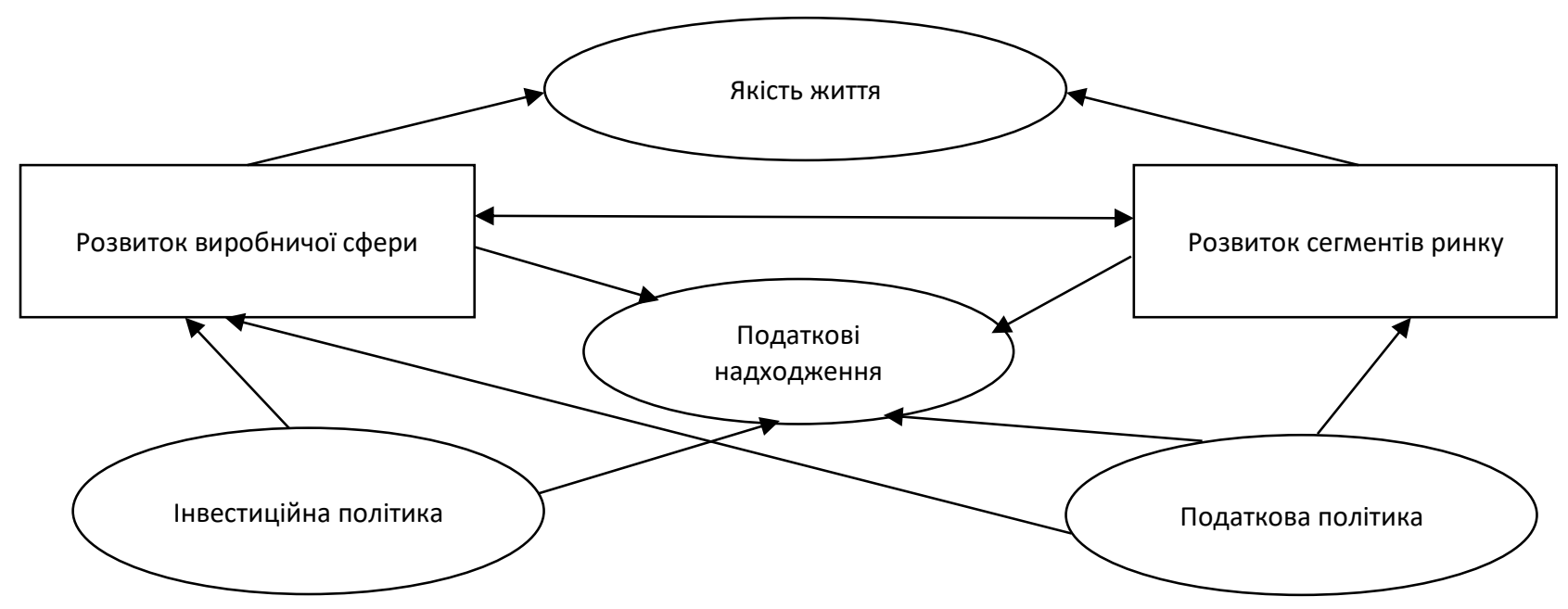

Рисунок 2 - Модель впливу інвестиційної та податкової політики на якість життя населення

Джерело: побудовано авторами на основі [3]

Відкритість європейського ринку праці для українців, зумовлюють необхідність дослідження особливостей формування і використання грошових доходів вітчизняних домогосподарств та обґрунтування необхідності підвищення їх ролі у формуванні гідного рівня життя українців. Враховуючи високий рівень мобільності сучасної молоді, Україну, вже в найближчій перспективі, може очікувати ситуація, коли навантаження пенсіонерів на працюючих перевищить критичний рівень [4].

При аналізі факторів, що впливають на якість життя населення, не виділяють територіальні, регіональні фактори, які визначають особливості формування і зміни якості життя населення на сучасному етапі соціально-економічного розвитку країни й окремих їі регіонів. У той самий час, за допомогою такої класифікації факторів можна буде оцінити особливості формування якості життя населення окремих регіонів, встановити суб'єктивну оцінку умов життєдіяльності в них та обґрунтувати пропозиції щодо принципів, завдань і заходів концепції підвищення якості життя населення регіону.

Важливим індикатором якості життя $\epsilon$ індекс інтелектуального потенціалу суспільства. Інтелектуальний потенціал суспільства відображає рівень освіти населення та стан науки в країні. При розрахунку індексу інтелектуального потенціалу враховується рівень освіти дорослого населення, питома вага студентів у загальній чисельності населення, частка витрат на освіту у ВВП, питома вага 
зайнятих у науці та науковому обслуговуванні в загальній чисельності зайнятих, питома вага витрат на науку у ВВП.

Індикатором якості життя $€$ також людський капітал на душу населення. Він відображає рівень витрат держави, підприємств і громадян на освіту, охорону здоров'я та інші галузі соціальної сфери в розрахунку на душу населення. Чим вище рівень економічного розвитку країни, тим вищий рівень людського капіталу і його питома вага в структурі всього капіталу.
Висновки. Якість життя населення - інтегральне поняття, яке передбачає аналіз усіх сфер життєдіяльності суспільства. Підвищення якості життя $€$ критерієм і необхідною умовою людського розвитку. За показниками відтворення населення та соціальної сфери Україна не надто відстає від європейських країн. Для більшості регіонів держави характерні високі показники відтворення населення, соціального стану та освіти. Покращення потребують економічні індикатори (зайнятість, умови й оплата праці, умови проживання).

\section{Література:}

1. Ватченко О. Б. Виникнення та аналіз поняття «сталий розвиток». Вісник Дніпропетровської державної фінансової академії. 2011. Вип. 1. С. 64-68.

2. Голубець М. А. Геосоціосистемологія - теоретична основа еколого-суспільно-економічного прогресу. Вісник НАН України. 2014. Вип. 6. С. 31-40.

3. Котикова О. І. Зміст поняття сталого розвитку. Науковий вісник Волинського державного університету ім. Лесі Українки. 2007. №12. C.173.

4. Котикова О. І., Краснюк А. О., Кавецька В. С. Доходи населення як основний індикатор рівня життя в умовах євроінтеграції. Економічна наука. 2017. №9 С.28-33.

5. Оробець І. Історико-генетичний підхід у дослідженні еволюції концепції сталого розвитку. Вісник КНУ ім. Тараса Шевченка. 2015. Вип. 8. С. 98-101.

6. Офіційний сайт Державної служби статистики України. URL: http://www.ukrstat.gov.ua.

7. Про затвердження Державної стратегії регіонального розвитку на період до 2020 року : Постанова КМУ від 06.08.2014 p. № 385. URL: http://search.ligazakon.ua/__doc2.nsf/link1/KP140385.html].

8. Сморжанюк Т. П. Сталий розвиток в умовах глобалізації та його складові. Економічні інновації. 2013. Вип. 53. С. 253-260.

9. Шевченко Ю. О. Розвиток «зеленої економіки»: національний аспект. Бізнес Інформ. 2013. № 3. С. $186-191$.

\section{References:}

1. Vatchenko, O. B. (2011). The emergence and analysis of the concept of sustainable development. Bulletin of the Dnipropetrovsk State Financial Academy, 1, 64-68.

2. Golubets, M. A. (2014). Geosociosystemology - the theoretical basis of ecological, socio-economic progress. Visn. NAS of Ukraine, 6, 31-40.

3. Kotikova, O. I. (2007). The content of the concept of sustainable development Scientific Bulletin of Volyn State University named after Lesya Ukrainka, 12, 173

4. Kotikova, O. I., Krasnyuk, A. O. \& Kavetska (2017). Population income as the main indicator of living standards in the context of European. Economic Science, 9, 28-33.

5. Orobets, I. (2015). Historical-genetic approach in the study of the evolution of the concept of sustainable development. Visn. KNU them. Taras Shevchenko, 8, 98-101.

6. Official site of the State Statistics Service of Ukraine. Retrieved from http://www.ukrstat.gov.ua

7. On approval of the State strategy for regional development for the period up to 2020: CMU Resolution of August 6, 2014 № 385. Retrieved from http://search.ligazakon.ua/I_doc2.nsf/link1/KP140385.html.

8. Smorzhanuk, T. P. (2013). Sustainable development in the conditions of globalization and its components. Economic innovations, 53, 253-260.

9. Shevchenko, Yu. O. (2013). Green Economy Development: A National Aspect. Business Inform, 3, 186-191.

Ця робота ліцензована Creative Commons Attribution 4.0 International License 